\title{
The Main Problems in the Relations Between the European Union and Turkey
}

\begin{abstract}
This paper depicts the dynamics of the EU-Turkey relations beginning from the signing of the association agreement, i.e. the Ankara contract, to date. In addition, it aims to specify the factors preventing the bilateral collaboration and achievement of EU membership as aspired to by Ankara.

The paper focuses on both the internal and international problems arising on Turkey's path to EU membership, namely, the westernisation trend originating from Kemal Ataturk times, recent developments in Turkey, the democratisation of political institutions, the rule of law and protection of human rights, regional security, Turkey's part in the refugee crisis, visafree travel, Greek-Turkey relationships, Ankara's stance towards Cyprus, the Kurdish problem, and the Turkey-US and Turkey-Russia relationships. The authors discuss the EU Member States' attitude towards the political and socio-economic developments in Turkey and the way Ankara looks at the requirements put forward by those Member States. We suggest several methods of rapprochement and brighter bilateral prospects.
\end{abstract}

Key words: Turkey, European Union, Relations, Membership

\section{Introduction}

Today, international relationships in Europe are hardly imaginable without shared values and relations with the EU.

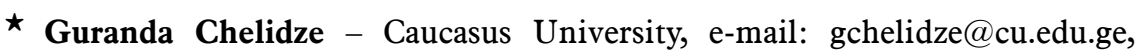
ORCID: 0000-0002-6233-8854.

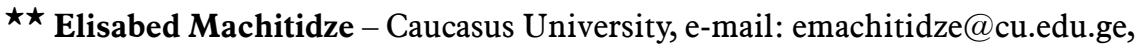
ORCID: 0000-0002-0971-7994. 
Georgia's westernisation has been the call of the day since the end of the Cold War and the collapse of the Soviet Union. Nearly two decades of EU-Georgia collaboration ended with the signing of the Association Treaty. Understandingly, in this context the experience of the other states, including Turkey, a neighbouring country and Georgia's strategic partner and a regional power, is of interest. Regardless of different historical backgrounds, given the regional developments, the issue is worth investigating; Turkey an important player in the international arena largely due to its location on the crossroads between the two continents and its vicinity to oil rich regions, the Caucasus and Middle East and also due to the fact that it has the Bosporus and Dardanelles Straits on its territory.

The Republic of Turkey, with just 3\% of its territory situated in Europe, is not an EU Member State although it executed the Association Treaty with EEC as early as 1963. This paper focuses on the dynamics of the Turkey-EU relationship, the problems and the views regarding the ways they may be settled in.

There are several other reasons as to why the issue is worth dealing with: the long-standing EU-Turkey relationships and Ankara's long drawn-out integration into the European Union prevented by largely the situation in the country - the slow development of the democratic institutions, the human rights problem, Turkey's part in the refugee crisis, visa-free travel, the Greece-Turkey relationship, Ankara's stance towards Cyprus, the Kurdish problem, and the Turkey-US and Turkey-Russia relationships. ${ }^{1}$ The authors discuss the EU Member States' attitude towards the political and socio-economic developments in Turkey and the way Ankara looks at the requirements put forward by those states. We suggest several methods of rapprochement and brighter bilateral prospects.

\section{Turkey-EU: Historic Background}

In his study "Turkey and Europe in History", Halil Inalc1k, the prominent Turkish historian, speaks about the beginnings of TurkishEuropean relations dating back to XV-XVI cc. ${ }^{2}$ However, the aspiration to join Europe gained ground 100 years ago, when westernisation was

\footnotetext{
1 See more: Turkey and Europe, ed. A. Szymański, The Polish Institute of International Relations, Warsaw 2012; A. Adamczyk, The Influence of Turkey's International Problems upon the Process of Its Integration with the European Union, in: Poland and Turkey in Europe - Social, Economic and Political Experiences and Challenges, Warsaw 2014, pp. 373-403.

${ }^{2}$ H. Inalcik, Turkey and Europe in History, Istanbul 2016, pp. 178-194.
} 
declared the uppermost principle of joining the European community of nations. ${ }^{3}$ The trend is still strong regardless of the Turkish secular circles' view about the "Erosion of Atatürk's legacy, which poses a threat to the policy of westernisation". ${ }^{4}$ As Mr. Ahmed Davutoğlu, the Turkish Foreign Secretary between 2009-2014 and later the leader of the ruling Justice and Development Party said, "For Turkey, integration into Europe is a strategic choice and one of the most important projects". ${ }^{5}$ However, the road to the EU has been pretty bumpy. Despite its Association Treaty with the EEC of 1963 and the Turkey-EU Customs Union of 1996, Turkey has been unable to achieve its ultimate goal of attaining EU membership. Ankara's application for EU membership - filed in 1987 during the Premiership of Mr. Turgut Özal - is still unsatisfied. Also, at the time, Turkish citizens were allowed to file individual claims to the European Court of Human Rights and the Parliament ratified the European Convention for the Prevention of Torture, and Inhuman or Degrading Treatment or Punishment. ${ }^{6}$ The second stage of Turkey-EU relations should be of interest for it was in December 1997 that the basics and dates of the EU expansion were defined at the Luxembourg summit. However, Turkey was sidelined from the expansion process. At the Helsinki summit in 1999, Turkey was granted the "candidate country" status and given access to "the strategy of achieving full-scale participation", i.e. similarly to the other aspirant states, carry out the reforms to make the country's political and economic institutions comply with the EU standards. ${ }^{7}$ The candidate-country status made Ankara hopeful that relations with Europe would take a better turn, ${ }^{8}$ all the more so that between 1995-2004, the EU issued lbn euros to fund consultative and translation services, the education system, seminars, forums etc. ${ }^{9}$ However, even negotiations launched in 2005 came to nothing.

${ }^{3}$ M. Komakhia, Turqet-evrokavshiris urtiertoba, Saqartvelos strategiuli kvlevebisa da ganvitarebis centri, „Biuleteni”, no. 41/2000 August, p. 2.

4 R. Gachechiladze, Saqartvelo msoplio konteqstshi: XX da XXI saukuneebis politikuri ckhovrebis ziritadi momentebi, Tbilisi 2017, p. 596.

5 B. Davutoğlu, AB'ye üyelik stratejik tercih olmaya devam ediyor [Elektronik kaynak] // AB Haber ve Politika Portalı [Resmi Kaynak], 10.05.2013, http://www.euractiv. com.tr/yazici-sayfasi/article/davutoglu-abye-uyelik-stratejik-tercih-olmaya-devamediyor-027749 (access 9.03.2021).

${ }^{6}$ C.V. Findley, Modern Türkiye Tarihi, İstanbul 2011, p. 356.

7 A. Gadjiev, Process Vstuplenia Turcii v ES I Kopengagenskie kriterii, Sovremennaia Turcia: Problemi i Reshenia, Sbornik, Moskva 2006, p. 124.

${ }^{8}$ M. Komakhia, op.cit., pp. 2-4.

9 A. Gadjiev, op.cit., p. 129. 
The key problem should be putting the Copenhagen criteria into practice. In "The regular Report on Turkey's Progress", "political criteria" were set out by way of 5 issues: which laws did the Turkish parliament adopt according to EU criteria; which bill did the Government prepare in compliance with the EU laws; to what extent are the powers of the Turkish military restricted, had the judiciary been reformed, and whether the fight against corruption had been institutionalised, and namely what legal and administrative acts had been enacted. ${ }^{10}$ Here we should also mention "the state governance reform package" wherein in its report, the EU leadership stated that if it was successfully implemented in Turkey's administrative and political system, significant steps would be taken towards modernisation of "Turkey's administration culture". ${ }^{11}$ Besides, there were requirements for each candidate country to meet which was crucial for the EU approach to it. Those defined for Turkey by the 1999 Helsinki summit obliged it to peacefully solve the border issues and settle relations with Cyprus.

Ankara was repeatedly told by Brussels that it did not comply with the "Copenhagen criteria". ${ }^{12}$ In September 2006, the European Parliament voted for the report that Turkey's progress towards the freedom of expression, minority rights, corruption combat and violence against women was insufficient. In November of that year, the Commission published a critical report concerning Turkey's compliance with the EU standards, saying that the border problems and relations with Cyprus remained unsolved. Many Turks believed that the EU's attitude to their country was too stringent, biased, and that it was just a "pretext"13 which had nothing to do with the named problems but portrayed a civilisational difference. It should be said, though, that the "creation of the Customs Union marked a significant step towards rapprochement between the two. The European states were trying to show the Islamic world that religious differences did not create obstacles to integration". ${ }^{14}$

In the mid 1990s, Turkey turned its gaze towards the development of democracy, human rights, and civil society important in its further relations with Europe. Turkey's EU membership also mattered; on the one hand,

10 Ibidem, p. 130.

112004 Regular Report on Turkey's progress towards accession, COM(2004) 656 final, Brussels, 6.10.2004, https://ec.europa.eu/neighbourhood-enlargement/sites/ near/files/archives/pdf/key_documents/2004/rr_tr_2004_en.pdf (access 10.03.2021).

12 R. Gachechiladze, op.cit., p. 599.

13 The activity of the EU and its mechanism of spreading democracy named "Conditionality" is highly actual today in Political Science and International Relations.

${ }^{14}$ M. Komakhia, op.cit., p. 5. 
as a NATO member state, it was closely involved in the liquidation of the Soviet legacy and on the other, strived for participation in the creation of the new political architecture in Europe ${ }^{15}$ And yet, by 2000, Turkey's EU membership, i.e. the "Copenhagen criteria", prevented its integration with Europe. Turkey's potential to share EU political and economic standards was disregarded, which prompted Ankara's claim about its discrimination and the EU's failure to apply the same criteria to all the candidate states. According to the 2003 poll taken by the Turkish Association for Social and Economic Studies, $62 \%$ of Turks believed that the EU was unfair to their country since the conditions it applied to Turkey were different from those set for the other candidate states. ${ }^{16}$ In the wake of the Cold War, political priorities in the EU changed as demonstrated by the admission of the Central and Eastern European countries, while Turkey was pushed back. The Kurds' and Cyprus issues still remained at the top of the agenda.

\section{Relations in the Last Decade - The Main Obstacles on Turkey's Path to the EU}

At the first Turkey-EU summit in Brussels on 29 November 2015, the parties agreed to rekindle its EU membership process. To this end, several hot issues were singled out for Ankara to work on:

1. A galvanisation of the EU membership talks;

2. Regular Turkey-EU summits to discuss critical issues;

3. Acceleration of the free-travel dialogue;

4. The drawing up and implementation of an action plan;

5. Refugee shelters;

6. The resumption of the Customs Union. ${ }^{17}$

In 2015-2016, the Turkey-EU talks intensified but were halted by an attempted military coup on 15 July 2016, the Government's harsh response and suspension of financial aid by the EU in the wake of that response. In 2019, the European Parliament suspended talks with Ankara. From this perspective, while assessing the Turkey-EU relations we should focus on the problems emerging in the bilateral negotiations:

15 Ibidem, p. 5.

16 U. Kudriashova, Perspektivi Dalneishego Sblijenia Turcii s Evropeiskim Souzom I Ego Posledstvia Dlia Rossii (Перспективы Дальнейшего Сближения Туричи с Европейским Союзом и его последствия для России), „Востоковедный Сборник”, no. 8/2007, p. 113.

17 Türkiye-AB Zirvesi Bugün Brüksel'de Gerçekleştirildi, 2 December 2015, Retrieved From T.C. Dışişleri Bakanlığı, Avrupa Birliği Başkanlığı, http://www.mfa.gov. tr/Turkiye_Nin-Kibris_La-Ilgili-Deklarasyonu_-29-Temmuz-2005.Tr.Mfa (access 10.03.2021). 
- the 15 July 2016 attempted military coup and the subsequent developments;

- deteriorated relations with the US, which worsened the economic situation in Turkey;

- establishment of close political ties with Russia;

- Ankara's request to reform the UN Security Council;

- developments in terms of the Turkish-Greek relations.

In 2018, Recep Tayyip Erdoğan was reelected President. At the same time, the Parliament adopted the Constitutional amendment envisaging Turkey's transformation from a Parliamentary to a Presidential Republic. Here we should say that in recent years, problems concerning the management of the refugee crisis and the aforementioned attempted military coup in July 2016 emerged in the EU-Ankara relations. Namely, Europe expressed concern about the increased Presidential powers, the crackdown on dissent, the restrictions imposed on the freedom of expression and the Media, the referendum on the Constitutional amendment and the appointment of the early Presidential and Parliamentary polls. On his part, President Erdoğan voiced his concern about the West's negative attitude towards his policies and established closer ties with Russia in connection with the war in Syria and his wish to acquire weaponry. While the EU Member States debate over the termination of talks with Turkey, the negotiations continue. Many States support continued economic relations as an alternative to Turkey's EU membership. They also suppose that the Brexit model could be applied to Ankara. For all the hurdles, EU membership, which is likely to boost the potential of the reforms and the dialogue on a common standard, especially so in terms of human rights, remains both sides' ultimate goal.

A closer look at the developments in recent years demonstrates that the public in Istanbul and Ankara stood up against an attempted military coup of 15 July 2016 staged by a group of officers looking to seize power. Responding to EU and NATO condemnation of Ankara's actions in the wake of the failed coup, the Turkish Government expressed disappointment; describing it as an attack against Turkey's democratically elected Government and bemoaning the lack of support from the EU and NATO. The EU reacted negatively against Erdoğan's statements about the reintroduction of the death sentence which had been abolished in 2004, the introduction of emergency rule and the persecution of innocent people, including the younger generation. The Turkish Government imposed a strict control over the Media, curbed social media and the Internet, closed down opposition newspapers and limited the freedom of expression. According to the Freedom House report, it was between 
2015-2018 when EU-Turkey relations worsened radically. A 16 April 2017 referendum on the Constitutional amendments came up as a response to the attempted coup. The amendments expanded Presidential powers and transformed the country from a Parliamentary to a Presidential Republic. An OSCE Observer Mission criticised the referendum organisers for limited public discussions and the restriction of the other candidates' opportunities to wage their campaigns in the run-up to the 2018 Presidential poll. The Justice and Restoration Party came out the winner of the early Parliamentary and Presidential election on 24 June 2018 and Recep Tayyip Erdoğan was elected President. The Constitutional amendments were enacted and Turkey became a Presidential Republic. On 25 July 2018, the Parliament approved a counter-terrorism package envisaging certain restrictions, which frustrated the Opposition. As a result of the Constitutional amendment, Turkey shifted from the European government model and, understandably, complicated its relations with the EU. ${ }^{18}$

Turkey-EU relations were also influenced by the crisis of the Turkish lira. Ankara refused to release Andrew Brenson, an American pastor suspected of being involved with the developments of 2016, from prison. Washington responded with increased tariffs on the metals imported from Turkey and imposed financial sanctions on some Turkish high officials. The US-Turkey stand-off poses a certain threat to the implementation of some major projects (a new airport and "the Istanbul Canal" to operate along with the Strait of Bosporus), the key issue in Erdoğan's pre-election program, which aimed at heightening Ankara's profile in the run-up to the 100 year anniversary since the establishment of the Republic of Turkey.

It should be said that the uncertainty and distrust characteristic to US-Turkey relations are unlikely to disappear any time soon. ${ }^{19}$ However, the settled bilateral ties are extremely important in terms of the implementation of the major projects similar to the ones mentioned above. In this regard, it is enough to remember that due to the situation in the region and Washington's pragmatic military policies, Turkey received considerable US military and economic aid in the 1980's, with which to support its further economic advancement. ${ }^{20}$

The question which arises in the discussion on the EU-Turkey relationship is whether there have been any changes within the alliances.

${ }_{18}$ Z. Batiashvili, Cvlilebebi turqetis mmartvelobis sistemashi, eqspertis azri, 107, Tbilisi 2018, p. 13.

19 E. Makaradze, Turqetis istoria 1918-2018 clebsi, Tbilisi 2019, p. 276.

20 E. Machitidze, 1980-iani clebis turqeti da amerikis seertebuli statebi, narkvevebi turqetis istoriidan, Tbilisi 2018, p. 206. 
In recent years, Turkey has been sending somewhat mixed signals about its collaboration with NATO and the EU membership issue. Turkey relied on NATO support in averting Russian threats as one of their F-16 fighter jets shot down a Russian plane. However, with the deterioration of USTurkish relations, President Erdoğan became vociferous about his close ties with Russian high officials and even made an attempt at procuring military equipment. It should be said, though, that rapprochement has been made possible by the geo-political situation, gradual estrangement from the West and also an ideological shift as the Justice and Development Party came to power.

By forging close ties with Moscow, Ankara seeks for stronger influence on Syria's prospects. As to Washington's attitude towards the TurkishRussian military cooperation, it is understandingly negative. The US and some of the NATO member states backed up the Kurdish military formations in northern Syria and stood against the creation of a buffer zone along the Turkish-Syrian border, which allowed approx. $3 \mathrm{mln}$ refugees to leave Turkey. Ankara supported Iran and Russia in the Syrian war and even participated in tri-partite negotiations.

In the last 15 years, Turkey has been trying to direct its political vector to Central Asia and Azerbaijan, where it has very strong cultural ties. It boosted its presence in the Organization for Islamic Cooperation (OIC), and hosted its summit in 2016 during which Ankara accused the West of double standards where Muslims are concerned. Similarly to the other G-20 member-states, for instance Brazil, it called for UN reform, especially so of the United Nations Security Council with its permanent seats that President Erdoğan described as "a one-sided system". He voiced his concern that none of the Islamic States were represented in the United Nations Security Council and expressed support to the system that would involve all the continents and religions. Neither the EU, nor England or France - permanent Security Council members - made their stance public regarding the issue.

Turkey is a NATO and a CoE member-state and the EU has strong trade interests there. Therefore, both the West and Ankara have taken a common stance with regard to two problems: Syria and terrorism combat in the region. The $\mathrm{CoE}$ gave a green light to the European Commission with regard to the latter problem, so the European Parliament is going to boost collaboration with Turkey not only in the fight against terrorism, but data sharing as well. Although in April 2016, Turkey signed the Paris treaty on climate change, Ankara's stance is not quite clear-cut and Turkish diplomats have repeatedly asked for a discussion on their country's stance in view of "special circumstances". 
Given the political situation in Turkey at the time, European leaders started thinking whether to continue debates over its admission to the EU, with some of the key players sounding pessimistic. In 2017, German Foreign Secretary Sigmar Gabriel claimed that due to a possible reintroduction of the death penalty in Turkey and the ungrounded detention of German citizens there, the earlier peaceful relations with Brussels could come to an end one day. ${ }^{21}$ It also became evident that along with Germany, neither France nor the Netherlands would have liked the annual NATO summit to be held in Istanbul in 2018, which was more evidence of EU-Turkey tensions. However, they agreed with some of the other states saying that talks with Ankara should go on in order to bring Turkey closer to the European values and living standards. In their words, despite slow progress, the negotiations should be regarded as an impetus to further development. We suppose that modernisation of the Customs Union in 2015, supposedly an alternative to Turkey's EU membership, is actually only a part of it. Speaking within the context, the refugee crisis and Ankara's part in its management, as well as possible visa-free travel should be considered a step forward towards EU membership. It was via Turkey that the refugees arrived in the EU, and Ankara has played a major role in the deterrence of migrants. In March 2016, Ankara agreed to return illegal migrants reaching the EU via Turkey unless they needed international support. This is an important point, since it had been because of the soaring numbers of migrants from the Middle East and North Africa to Europe that prompted the EU to conclude an agreement on the refugee crisis with Ankara in March 2016. As is well known, by signing the agreement, Turkey assumed an obligation to deter migrants on its territory on several conditions. Those included, but were not limited to, the allocation of $3 \mathrm{bn}$ euros by the EU for accommodation of the migrants, the acceleration of EU membership and visa-free travel for Turkish citizens as early as the end of 2016. The agreement significantly curbed the refugee influx into the EU states for which they allotted $677 \mathrm{~m}$ euros. However, due to the developments in Turkey, the EU did not meet the other conditions. ${ }^{22}$ Ankara's call for a revision of the agreement on migrants further complicated the situation. Turkish government officials referred to the changed circumstances since 2016 and requested free travel and an improvement of the Customs Treaty. They grounded their demands on the fact that there were approximately 3.5 million migrants in their country at the time and emphasised President Erdoğan's proposal to create safety zones in Syria and the return of the refugees. It may be

${ }^{21}$ https://imedinews.ge (access 10.03.2021).

${ }^{22}$ https://1tv.ge/analytics/turqetis-evropuli-perspeqtivis-daisi/ (access 10.03.2021). 
said that Turkey took on one of the biggest challenges facing Europe and contributed significantly to international efforts. Not only is it hosting 3.5 million Syrian refugees, but it has also prevented their arrival in Western Europe by the thousands via the hazardous route across the Aegean Sea.

However, on 27 February 2020, President Erdogan stated that the Government was no longer going to bar Syrian refugees' influx into Europe, all the more so that 33 Turkish servicemen had been killed in Idlib by the Syrian regime. Incidentally, he also remarked that the Greek border was open. His remark did not come up as totally unanticipated for as early as 2018, experts said that the "Turkish leaders continuously threatened Brussels with the prospect of unsealing the border" and that "the EU decision-makers were wavering over the prospect of lifting visas". ${ }^{23}$ Ankara's steps resulted in the concentration of around 12,500 refugees on the Turkish-Greek border. The situation was aggravated by Athens's protest against Ankara's allegations that the Greeks had shot a refugee trying to cross the border. The EU warned Turkey that „Illegal crossings will not be tolerated. In this regard, the EU and its member states will take all necessary measures, in accordance with EU and international law... Migrants should not be encouraged to endanger their lives by attempting illegal crossings by land or sea". ${ }^{24}$

The EU Interior Ministers' meeting in Brussels claimed that Ankara was exploiting the refugee problem for political reasons. Mr. Charles Michel, President of the European Council and Mr. Josep Borrell, the EU High Representative of the Union for Foreign Affairs and Security Policy, got closely involved in solving the issue. However, President Erdogan maintained a rigid stance, saying that Ankara was not going to revise the refugee agreement with Europe until the EU supported its military inroads in Syria, something that the French Foreign Secretary described as "blackmail". We agree with Mr. Borrell's view that opening European borders would seriously undermine the EU's trust in Turkey. Turkey should remain true to its obligation under the 2016 Agreement between Brussels and Ankara. We believe that Ankara should reconsider its position where the issue is concerned.

The concept of the so-called "new orbit", i.e. a common status for Turkey and Britain, is of interest, too. On 23 June 2016, when Britain declared its intention to leave the EU, the latter had been considering

${ }^{23}$ L. Haferlach, F. Tekin, J. Wódka, Friends. Foes. Frenemies? Unpacking the future of EU-Turkey Relations, "Futures", no. 97/2018, p. 54.

${ }^{24} \mathrm{https}$ //www.dw.com/en/eu-strongly-rejects-turkeys-use-of-migrants-at-border/ a-52640976 (access 21.04.2021). 
stepping up relations with Ankara to compensate for Brexit, but changed its policies because of President Erdogan's harsh response to the dissent.

Incidentally, in his "History of Turkey" published back in 2007, Michael Svanidze pointed out the rapid increase of the population as a negative factor in terms of Turkey's EU membership: if admitted, it would have been the most populous EU state, with its parliamentary quota equal or perhaps even larger than that of the key EU countries. ${ }^{25}$ Considering that Turkey's population is about 84 million today, it is a significant factor in terms of its EU membership. ${ }^{26}$ Quite a few authors say that "Europe is to be concerned by Turkey's demographic potential and a rapid natural growth of its population". ${ }^{27}$ They also point at the religious, cultural, and linguistic differences. ${ }^{28}$

The EU sanctions imposed on Ankara in 2020 for the unsanctioned exploitation of natural resources in the eastern Mediterranean added to the problem. The tensions increased in August when Ankara sent a ship for natural gas reconnaissance in the waters that Greece regarded its own. A Turkish-Greek dispute over drilling rights flared. EU sanctions were applied to the companies responsible for drilling in the disputed waters of the Mediterranean Sea. Ankara brushed aside the economic sanctions, saying that the EU was being unfair towards Turkey for aspiring for its membership and that the Union's claim that it was escalating tensions was false. Ankara requested improved relations on the grounds of its full EU membership. A telephone conversation between Turkish President Erdoğan and the European Commission President Ursula von der Leyen, as well a meeting in Brussels between Turkey's Foreign Secretary Mevlüt Çavuşoğlu and Mr. Josep Borrell, the EU Minister for Foreign Affairs during which the European official said that the EU had a strategic interest in developing cooperative and mutually beneficial relations, generated some hope. The meeting made a candid and exhaustive exchange of opinions possible. The sides welcomed the CE's decision in December to submit a report on the status of the EU-Turkey's political, economic, and trade ties and their prospects. ${ }^{29}$ As the Turkish Foreign Minister Mevlüt Çavuşoğlu said, "2020 was problematic in terms of EU-Turkey relations

${ }^{25}$ M. Svanidze, turqetis istoria, Tbilisi 2007, p. 543.

$26 \mathrm{https} / /$ www.worldometers.info/world-population/turkey-population/ (access 10.03.2021).

27 R. Gachechiladze, op.cit., p. 600.

${ }_{28}$ K. Karpat, Kısa Türkiye Tarihi: 1800-2012, Istanbul 2012, p. 233.

29 https://eeas.europa.eu/headquarters/headquarters-homepage/91878/euturkey -high-representativevice-president-josep-borrell-foreign-minister-mevl\%C3\%BCt$\% \mathrm{C} 3 \% \mathrm{~A} 7 \mathrm{avu} \% \mathrm{C} 5 \% 9 \mathrm{Fo} \% \mathrm{C} 4 \% 9 \mathrm{Flu}-w a y \_$en (access 10.03.2021). 
but the dialogue took a more positive turn after the European leaders' meeting in December. Turkey is always ready for relations with any party or institution that will stretch out a positive hand", adding that his country was keeping its promise; "However, only one side's wish or loyalty is not sufficient where bilateral relations are concerned. I'd like to say that in the conversations with my colleagues I saw a very positive attitude and the wish to improve our relations" ${ }^{30}$ Foreign Minister Mevlüt Çavuşoğlu expressed hope that Turkey's admission process would continue, adding that Ankara was ready for further negotiations to meet EU criteria. ${ }^{31}$ Here we should mention the European Commission's 2020 report on Turkey that states: "Regarding its ability to assume its obligations of membership, Turkey has continued to align with the EU acquis, albeit at a very limited pace and in a fragmented manner. There continued to be instances of backsliding regarding a number of key aspects in the areas of competition on account of an increase in State aid and its lack of transparency, information society and media, economic and monetary policy, customs union, external relations and foreign, security and defence policy. Turkey is well advanced in the areas of company law, trans-European network and science and research, and it has also achieved a good level of preparation in a number of areas, including the free movement of goods, intellectual property law, financial services, and enterprise and industrial policy. Turkey is also moderately well prepared on public procurement despite the fact that important gaps remain in its alignment. Turkey is also relatively well prepared in areas such as the free movement of capital, transport policy, energy, taxation, economic and monetary union, statistics, where further significant efforts are needed across the board. Overall, more ambitious and more coordination policies still need to be established and implemented. In all areas, more attention needs to be given to enforce legislation whilst many areas require further significant progress to achieve legislative alignment with the EU acquis, to strengthen the independence of regulatory authorities, and to build administrative capacities" ${ }^{32}$ It also has to be kept in mind that: "The first half of 2020 has been marked by the devastating impact of the COVID-19 pandemic. The EU redirected EU funds worth 83 million to support the COVID-19 response in Turkey, notably to support the most vulnerable refugees, and

\footnotetext{
${ }^{30}$ https://www.aa.com.tr/en/europe/eu-turkey-to-work-on-new-roadmap-topturkish-diplomat/2119665 (access 10.03.2021).

31 Ibidem.

32 Commission Staff Working Document, Turkey 2020 Report, Brussels, 6.10.2020, p. 9, https://ec.europa.eu/neighbourhood-enlargement/sites/near/files/turkey_report_2020.pdf (access 10.03.2021).
} 
extended implementing periods for some IPA programs. In the context of the Facility for Refugees in Turkey, the Commission immediately launched awareness raising activities for the refugee population who are among the most vulnerable people. An agreement was reached with the Turkish government to mobilize savings and contingencies under the Facility to support the national COVID-19 response". ${ }^{33}$ Apparently, the fight against the pandemic has also influenced the further development of bilateral relations, which is of course the right approach.

Prof. İran Kaya Ülger of Kocaeli University expressed an interesting view on the current Turkey-EU relations: “Turkey's ambition for EU membership is right. Historically speaking, the West has been influential in the improvement of democracy and basic rights and freedom in Turkey. For instance, Turkey's transformation to a multi-party regime in 1946 occurred under the pressure of the European Council. Likewise, the increase in Turkey's prosperity also became possible thanks to its close ties with the EU. The Custom Union Treaty of 1996 between Turkey and the EU boosted the flow of foreign direct investment to Turkey and hence increased the per capita income. Turkey is right in thinking that the EU wouldn't allow it in anyway. Uncertainty on Turkey's membership seems to have been derived from the EU. Yet, the situation is a bit more complicated" ${ }^{34}$ We share Prof. Dr. İrfan Kaya Ülger's views based on the historical context of the EU-Turkey relations. He speaks about the EU free trade agreement (ESTA), which will support the free movement of goods, services, capital, and people between Turkey and the EU. ${ }^{35}$ Regardless of the EU's cautious approach, "Turkey has become a regional power to be reckoned with, but its international agenda is not well aligned with the EU's and its methods are not those of the EU". ${ }^{36}$ "Mutual expectations from the 2016 EU-Turkey Joint Statement, which followed the outbreak of the migration crisis of 2015 had not borne fruit". ${ }^{37}$ We suppose that the 2020 dynamics of the developments create positive expectations where the Turkey-EU prospects are concerned. The fact that “...the EU will be unable to achieve stability on the Continent unless it balances its relations with Turkey also generates hope". ${ }^{38}$ It is but logical since the European

33 Ibidem, p. 10.

34 https:/www.aa.com.tr/en/europe/turkey-is-part-of-europe-and-will-be-partof-new-eu/2141014 (access 1.03.2021).

35 https://www.aa.com.tr/en/europe/turkey-is-part-of-europe-and-will-be-partof-new-eu/2141014 (access 1.03.2021).

36 https://eeas.europa.eu/headquarters/headquarters-homepage/90861/way-ahead -after-difficult-2020-eu-turkey-relations-\%C2\%A0_en (access 1.03.2021).

${ }^{37}$ Ibidem.

38 Ibidem. 
integration had been prompted by the need to prevent conflicts on the Continent.

\section{Conclusions - Prospects of Turkey's EU Membership}

A state directs its international relations on the basis of its national and common interests and relies on them in its international dealings. This is also true for Turkey and the EU. The progress of Turkey-EU relations is a long-term affair. Ankara still has a long way to go to join the EU. ${ }^{39}$ Progress will largely depend on the international economic and political situation, as well as the Turkish Government's readiness to implement European values and legal reforms. The following is relevant to Turkey's westernisation: The goal of EU membership set decades ago remains the same as it is still important to both sides and a merely single step, and not even economic integration, is not going to create equal opportunities for either the EU or Turkey. Although Turkey's integration into the EU has slowed down, it is not at a standstill, and for both those in Europe and Turkey it is not considered against the background of the past but the future. ${ }^{40}$

Turkey is a signatory to the CoE Constituent and the European Human Rights Convention, which guarantees the respect of the people's personal rights both in European countries and in Turkey. Therefore, we may presume that with time, human rights are going to be as respected in Turkey as they are in all European states, and all the more so considering that the westernised Turkish population is quite numerous, politically active and that the Western mentality is gaining ground, especially so among the younger generation, who share the Western values of democracy and human rights.

Contemporary Turkish history depicts a continuous struggle between the authoritarianism of a robust state and democratic ideals. In terms of the rule of law and human rights, recent developments in the country make the authoritarian trend evident, something which creates problems in EU-Turkey relations. We believe that a stronger democratic rule in the country would step up Ankara's progress towards EU membership. In order to achieve its desired integration with the EU, Turkey will have to introduce European values and make more consistent efforts at democratisation.

Turkey is not a European state. It is situated on the crossroads between Europe and Asia, which is a definitive factor in terms of its geopolitical significance. If admitted into the EU, it is going to strengthen Europe's

39 K. Karpat, op.cit., p. 232.

40 Ibidem, p. 233. 
relations with rapidly growing regions such as the Caucasus and Central Asia, areas rich with energy resources. Turkey's unique strategic location and its military potential - the second largest in NATO - will be a major contribution to European security. The economic situation has also to be taken into consideration. Although some political analysts suppose that the EU is reluctant to admit Turkey because of the internal political and economic reasons, Ankara's economic potential should not be disregarded; it has lived up to the challenges created by the global economic crisis. Many people think that despite stable economic growth, Turkey may not be competitive on the EU market. If so, the already high unemployment is likely to increase and bring about the outflow of labour resources to the EU states. However, it may be said that after Brexit, Turkey may stimulate economic growth in Europe at the expense of job creation, i.e. the economy may support finding solutions to the migration problem. If we remember that today Turkey, “...participates in the following EU programmes: Erasmus+, Horizon 2020, Customs 2020, Fiscalis 2020, COSME (Competitiveness of Enterprises and Small and Medium-sized Enterprises) and EASI (Employment and Social Innovation). Since 2019 it has also participated in the European Solidarity Corps programme. Turkey participates in the European Environmental Agency, the European Monitoring Centre for Drugs and Drug Addiction and the Civil Protection Mechanism". ${ }^{41}$ It creates hope in terms of penetration of the European culture, education, science, and mentality into the Turkish population. The expectations are further boosted by the EU stance that: "We have a chance still to redirect our relations. The EU extends an open hand to Turkey hoping it will seize it". ${ }^{42}$ By this, the EU proves that it is not a closed community, is free from racial and religious prejudices and is ready to bring the Islamic world closer to democratic values and human rights, fundamental to a single Europe.

Therefore, for purely pragmatic reasons and mutual interests, both Turkey and the EU should carry on their partnership and for all the controversial developments, and take steps towards a closer collaboration based on the defined criteria. Otherwise, a positive agenda $\mathrm{a}^{43}$ could prove to be unattainable and a waste of time in an already long-drawn-out EU membership attempt.

${ }^{41}$ Comission Staff Working Document, Turkey 2020 Report, p. 115, https:// ec.europa.eu/neighbourhood-enlargement/sites/near/files/turkey_report_2020.pdf (access 10.03.2021).

42 Ibidem.

${ }^{43}$ N. Demiral, Positive agenda for Turkey-European Union relations: what will it bring or what will it take, "Procedia - Social and Behavioral Sciences", no. 143/2014, p. 1011, DOI: https://doi.org/10.1016/j.sbspro.2014.07.545. 


\section{References}

Adamczyk A., The Influence of Turkey's International Problems upon the Process of Its Integration with the European Union, in: Poland and Turkey in Europe - Social, Economic and Political Experiences and Challenges, eds. A. Adamczyk, P. Dubel, Centre for Europe University of Warsaw, Warsaw 2014.

Batiashvili Z., Cvlilebebi turqetis mmartvelobis sistemashi, „Eqspertis azri”, no. $107 / 2018$.

Comission Staff Working Document, Turkey 2020 Report, Brussels, 6.10.2020, p. 9, https://ec.europa.eu/neighbourhood-enlargement/sites/ near/files/turkey_report_2020.pdf (access 10.03.2021).

Demiral N., Positive agenda for Turkey-European Union relations: what will it bring or what will it take, „Procedia - Social and Behavioral Sciences”, no. 143/2014, DOI: https://doi.org/10.1016/j.sbspro.2014.07.545.

Esfahani H., Çeviker-Gürakar E., Fading attraction: Turkey's shifting relationship with the European Union, „The Quarterly Review of Economics and Finance", no. 53(4)/2013, DOI: https://doi. org/10.1016/j.qref.2013.10.001.

Findley C.V., Modern Türkiye Tarihi, Timas Yayinlari, İstanbul 2011.

Gachechiladze R., Saqartvelo msoplio konteqstshi: XX da XXI saukuneebis politikuri ckhovrebis ziritadi momentebi, Sulakauri Publishing, Tbilisi 2017.

Gadjiev A., Process Vstuplenia Turcii v ES i Kopengagenskie kriterii (Проuеcc Вступления Туриии в ЕС и Копенгагенские Критерии, Современная Туриия: Проблемы и Решения), in: Sowriemiennaja Turcja: Problemi $i$ Reshenia, Sbornik Statei (Современная Туриия: Проблемы и Решения Сборник Статей), Institute of the Middle East/ Institute of the Oriental Studies, Moscow 2006.

Haferlach L., et al., Foes. Frenemies? Unpacking the future of EU-Turkey Relations, „Futures”, no. 97/2018, DOI: https://doi.org/10.1016/j. futures.2017.04.006.

Inalcik H., Turkey and Europe in History, EREN Press, Istanbul 2016.

Karpat K., Kısa Türkiye Tarihi: 1800-2012, Timaş Yayınları, İstanbul 2012.

Kirac Z., et al., The United States of America Effect on Turkey-European Union Relations, „Procedia Economics and Finance”, no. 15/2014, DOI: https://doi.org/10.1016/S2212-5671(14)00643-1.

Komakhia M., Turqet-evrokavshiris urtiertoba, Saqartvelos strategiulikvlevebisa da ganvitarebis centri, "Biuleteni", no. 41/2000.

Kudriashova U., Perspektivi Dalneishego Sblijenia Turcii s Evropeiskim Souzom I Ego Posledstvia Dlia Rossii (Перспективы Дальнейтего 
Сближения Туриии с Европейским Союзом и его последствия для России), „Востоковедный Сборник”, по. 8/2007.

Machitidze E., 1980-iani clebis turqeti da amerikis seertebuli statebi, narkvevebi turqetis istoriidan, Klio, Tbilisi 2018.

Makaradze E., Turqetis istoria 1918-2018 clebsi, Universali, Tbilisi 2019.

Regular Report on Turkey's progress towards accession, COM(2004) 656 final, Brussels, 6.10.2004, https://ec.europa.eu/neighbourhoodenlargement/sites/near/files/archives/pdf/key_documents/2004/rr tr_2004_en.pdf (access 10.03.2021).

Poland and Turkey in Europe - Social, Economic and Political Experiences and Challenges, eds. A. Adamczyk, P. Dubel, Centre for Europe University of Warsaw, Warsaw 2014.

Saatçioğlu B., et al., AB-Türkiye Illişkilerinin Geleceği: Çatışmalı İsbirliği ve Dinamik Ortaklık, „FEUTURE Sentez Çalışması” 2019.

Souleimanov E., Turqeti da evrokavsiri: Titqmis evropuli Turqeti, „Liberali”, no. 48, October 18, 2010.

Svanidze M., Turqetis istoria, Artanuji, Tbilisi 2007.

Turkey and Europe, ed. A. Szymański, The Polish Institute of International Relations, Warsaw, 2012.

https://1tv.ge/analytics/turqetis-evropuli-perspeqtivis-daisi/ (access 10.03.2021).

https://www.aa.com.tr/en/europe/turkey-is-part-of-europe-and-will-bepart-of-new-eu/2141014 (access 1.03.2021).

https://www.dw.com/en/eu-strongly-rejects-turkeys-use-of-migrants-atborder/a-52640976 (access 21.04.2021).

https:/eeas.europa.eu/headquarters/headquarters-homepage/91878/ euturkey-high-represen tativevice-president-josep-borrell-foreignminister-mevl\%C3\%BCt-\%C3\%A7avu\%C5\%9Fo\%C4\%9Flu-way_en (access 10.03.2021).

https://eeas.europa.eu/headquarters/headquarters-homepage/90861/ way-ahead-after-difficult-2020-eu-turkey-relations-\%C2\%A0_en (access 1.03.2021).

http://www.euractiv.com.tr/yazici-sayfasi/article/davutoglu-abye-uyelikstratejik-tercih- olmaya-devam-ediyor-027749 (access 9.03.2021). https://imedinews.ge (access 10.03.2021). http://www.mfa.gov.tr/Turkiye_Nin-Kibris_La-Ilgili-Deklarasyonu_-29Temmuz-2005.Tr.Mfa (access 10.03.2021). https:/www.worldometers.info/world-population/turkey-population/ (access 10.03.2021). 